$\begin{array}{r}\text { Contents lists available at BIOSFER } \\ \text { BIOSFER: JURNAL TADRIS BIOLOGI } \\ \text { p-ISSN: 2086-5945 (print), e-ISSN: 2580-4960 (online), DoI 10.24042/biosfer } \\ \text { http://ejournal.radenintan.ac.id/index.php/biosfer/index } \\ \hline \hline\end{array}$

\title{
The Potential of Billygoat Weed Leaf Extract (Ageratum Conyzoides) in Increasing Platelet Counts of Male Mice (Mus Musculus)
}

\author{
Yessy Velina ${ }^{1 *}$, Nirva Diana ${ }^{2}$, Aulia Annisa ${ }^{3}$ \\ 1, 2,3Universitas Islam Negeri Raden Intan Lampung, Indonesia
}

\section{ARTICLE INFO}

\section{Article History}

Received: April 14th 2020

Accepted: May $18^{\text {th }}, 2020$

Published: June 29th 2020

Keywords:

Ageratum Conyzoide;

Platelets;

Mus Musculus

*Correspondence email: yessyvelina@radenintan.ac.id

ABSTRACT

Billygoat weed (Ageratum conyzoides) is mainly used to treat wounds and fever. People also do not understand the use of these leaves in the treatment to increase the platelet counts. The objectives of this research Objectives were to test whether the Billygoat Weed's leaves can increase platelet count of male mice and to find out what is the most effective dose of the Billygoat Weed on the platelet count of male mice. This research was done by employing the true experimental approach with the completely randomized design which consisted of 5 treatments, namely the negative control (plain water), the positive control (acetylsalicylic acid), $1.68 \mathrm{mg} / \mathrm{kgBW}, 2.52 \mathrm{mg} / \mathrm{kgBW}$, and 3.36 $\mathrm{mg} / \mathrm{kgBW}$ on five mice in each treatment. The increase in the platelet counts, based on the results of One-Way ANOVA with a p-value of 0,0004 , the Billygoat Weed extract was able to increase the platelet counts. Through further testing, the smallest significant difference showed that a dose of $3.36 \mathrm{mg} / \mathrm{kgBW}$ was effectively able to increase the platelet counts of male mice with an average of $11140.80 / \mathrm{mm}^{3}$.
\end{abstract}

\section{Potensi Ekstrak Daun Babandotan (Ageratum Conyzoides) Dalam Meningkatkan Jumlah Trombosit Pada Mencit Jantan (Mus Musculus)}

ABSTRAK: Ageratum conyzoides hanya dimanfaatkan untuk mengobati luka dan demam, masyarakat juga belum paham dalam pemanfaatan daun babandotan dalam pengobatan kenaikan jumlah trombosit. Tujuan penelitian 1). Menguji apakah daun babandotan mampu meningkatkan jumlah trombosit pada mencit jantan dan 2). Mengetahui berapakah dosis yang paling efektif dari ekstrak daun babandotan pada jumlah trombosit mencit jantan. Menggunakan true experimental dengan rancangan penelitian acak lengkap (RAL), terdiri dari 5 perlakuan; kontrol negatif (air biasa), kontrol positif (asam asetilsalisilat), 1,68 $\mathrm{mg} / \mathrm{gbb}, 2,52$ $\mathrm{mg} / \mathrm{gbb}$ dan 3,36 $\mathrm{mg} / \mathrm{gbb}$ dengan masing-masing perlakuan menggunakan 5 ekor mencit. Berdasarkan hasil peningkatan jumlah trombosit diuji menggunakan One Way ANOVA dengan pvalue 0,0004 maka ekstrak mempunyai pengaruh dalam meningkatkan jumlah trombosit dan dengan uji lanjutan beda nyata terkecil yang hasil 
menungjukan adanya peningkatan jumlah trombosit pada mencit jantan (Mus musculus) yaitu dosis 3,36 mg/gbb yang mampu meningkatkan jumlah trombosit dengan efektif dengan rata-rata $11140,80 / \mathrm{mm}^{3}$.

\section{INTRODUCTION}

Blood is vital for all humans because it has the function of sending substances and oxygen needed by the body tissues (Sugianto \& Zundi, 2017). Blood is composed of two parts, namely blood cells and blood plasma (Firani, 2018; Syam et al., 2016). Blood cells are composed of the blood cell (erythrocytes), white blood cells (leukocytes), and blood fragments (platelets) (Yolanda \& Kurnia, 2015; Yolanda \& Prayama, 2016).

Platelet plays an important role in hemostasis (Anwar, 2018; Motulo et al., 2015; Ujiani et al., 2018; Wirawan, 2007). Platelets have a function in the mechanism of blood protection to stop bleeding (Hajiriah \& Intan, 2019; Khasanah \& Suyadi, 2014). Platelet abnormalities, namely the thrombocytopenia and thrombocytosis (Bahctiar, 2019; Masihor et al., 2013; Yuliani, 2013), might be caused by many factors. Thrombocytopenia is an abnormality that emerges when the platelet count is less than normal amounts which are 150,000/ $\mu \mathrm{l}$ (Rasyada et al., 2014; Rofinda, 2012). Decreased platelet production in the bone marrow can be caused by a viral infection (Masihor et al., 2013; Utari et al., 2018; Zulkarnain et al., 2017), the maturation of the platelet precursor cells in the bone marrow, radiation, bone marrow aplasia, malignancy or cancer in bone marrow, as well as drugs that suppress the production of blood cells in the bone marrow.

The destruction of platelets in the blood can be caused by immune or nonimmune processes (Lubis et al., 2015). Primary diseases that are often associated with ITP are autoimmune diseases, especially the antibody and phospholipid syndrome, and viral infections including Hepatitis C, Human Immunodeficiency Virus or HIV (Wijaya, 2020), Cytomegalovirus, Epstein-Barr virus, Dengue virus, and certain drugs (Karsy et al., 2018).

research had been done on the effects of Billygoat Weed (Ageratum conyzoides) toward germination (Isda et al., 2013), larvae (Lumowa, 2011), and wet transport (Aini et al., 2014).

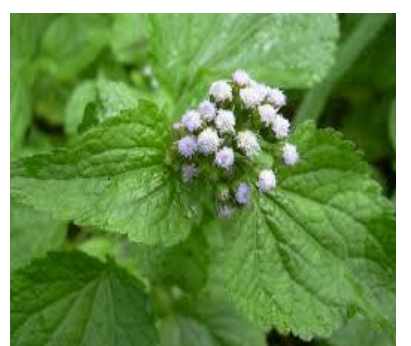

(a)

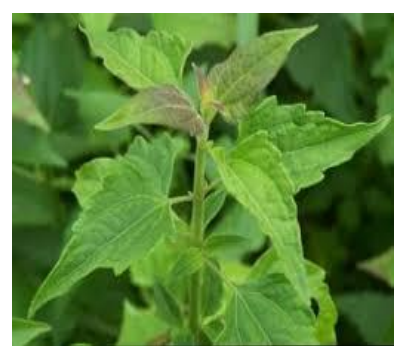

(b)
Figure 1. (a) and (b) Billygoat weed (Ageratum conyzoides)

However, research on the effects of Billygoat Weed (Ageratum conyzoides) in increasing platelet counts has not been done. Thus, this research tested the potential of Billygoat Weed leaf extract in increasing the platelet counts on male mice with reduced platelet counts.

\section{METHOD}

This laboratory study was carried out to examine the effects of Billygoat Weed (Ageratum conyzoides) leaf extracts in increasing platelet counts of male mice (Mus musculus) with thrombocytopenia. The instruments used were the M.1600 digital binocular microscope, glass object, and $1 \mathrm{ml}$ disposable syringe.

The mice were kept for about 4 days in storage with 12-hour lighting. The dosage of Billygoat Weed leaf extract in this research was adapted based on research on Betadine leaves (Jatropha multifida L.) conducted by (Sundaryono et al., 2016). On 
that research, the doses given to the mice were $0.056 \mathrm{~g} / \mathrm{kgBW}, 0.084 \mathrm{~g} / \mathrm{kgBW}$ and $0.112 \mathrm{~g} / \mathrm{kgBW}$. By converting the average body weight of mice (30 grams), the Billygoat Weed leaf extract given to the mice was $1.68 \mathrm{mg} / \mathrm{kgBW}, 2.52 \mathrm{mg} / \mathrm{kgBW}$, and $3.36 \mathrm{mg} / \mathrm{kgBW}$.

The blood was drawn from the tails of mice (Mus musculus). The platelet counts were determined by performing blood smears. The platelets were counted using a microscope within 24 hours after the treatments.

When extracting the blood from the mice's tails, the first drop of blood was removed and the next drop of blood was extracted with a syringe. The extracted drops of blood were placed at the upper end of glass objects to get good smear areas. The blood was then left alone to dry. After the blood had dried up, methanol drops were applied evenly and then once again left it to dry. Next, a small amount of Giemsa stain was applied to the dried-up blood on glass objects and then left them until the dye seeped into the blood. Lastly, the dyed glass objects were rinsed in distilled water.
Furthermore, to find the location of platelets, a microscope with an initial magnification of $4 \times 10$ was used and to see the platelets, a microscope with a magnification of $10 \times 0.25$ was used

The research data must be investigated for its normality. If the data is normally distributed, the One-way ANOVA test could be performed. Significant results can be said to be obtained or in other words, $\mathrm{H}_{\mathrm{o}}$ is rejected and $\mathrm{H}_{1}$ is accepted if the result of the One-way ANOVA is less than 0.05. A further test needs to be done using the Least Significant Difference test (LSD) at the 0.05 significance level to determine which treatment is more influential to increase mice's platelet counts. (Agus, 2011).

\section{RESULTS AND DISCUSSION}

The platelet counts were measured three days after the (P0), (P1), (P2), (P3), and (P4) treatments. The results can be seen in Table 1.

Table 1. Platelet Counts Measurement Three Days after the Treatments

\begin{tabular}{ccccc}
\hline Treatments & Repetition & \multicolumn{3}{c}{ Averages up to $\pm \mathbf{1 0}$ / mm } \\
\cline { 3 - 5 } & & H0 & H2 & H3 \\
\cline { 3 - 5 } & & $9799,40 \pm 362,551$ & $8490,40 \pm 1178,919$ & $7966,80 \pm 597,252$ \\
P(1) & & $8884,80 \pm 1050,190$ & $2224,60 \pm 665,269$ & $7737,80 \pm 650,901$ \\
P(2) & 5 & $8299,60 \pm 1315,173$ & $3762,40 \pm 1432,230$ & $7424,00 \pm 2085,591$ \\
P(3) & & $7983,20 \pm 868,923$ & $2273,80 \pm 1184,253$ & $9577,40 \pm 1206,261$ \\
P(4) & & $7983,20 \pm 1657,947$ & $3909,40 \pm 1138,475$ & $11140,80 \pm 2220,261$ \\
\hline
\end{tabular}

Based on Table 1, within two applications of acetylsalicylic acid (P1) on $\mathrm{HO}$ and $\mathrm{H} 2$, the platelet counts were reduced. The decreased platelet counts result in bleeding that cannot be stopped because the blood is difficult to clot. Thrombocytopenia is a condition where platelet counts drop below the normal levels. It might be caused by the failure of the bone marrow to produce platelets.
The application of acetylsalicylic acid to Mus musculus (P1) orally for 2 days resulted in a decreased platelet counts from 8884.80 (H0) to $2224.60 / \mathrm{mm}^{3}$ (H2). On the third day (H3), the platelet count increased to normal levels. This was due to the application of acetylsalicylic acid which was given orally for 2 days. On the third day, the application of acetylsalicylic acid was stopped so that the mice could recover. 
On the P4 treatment group, after the Billygoat Weed leaf extract had been administered, the platelet counts increased from 3909.40 on the second day to $11140.80 / \mathrm{mm}^{3}$ on the third day (H3). The Billygoat Weed leaf extract was able to increase the platelet counts of male mice with thrombocytopenia to normal conditions (P0) on the third day. Thus, the Billygoat Weed leaf extract has the potential to increase the platelet counts of male mice.

Flavonoid can inhibit platelet aggregation (Irawati, 2015; Shalehah et al., 2015), because it inhibits the release of Arachidonic acid by impinging cells so that the metabolism pathway of Cyclooxygenase is inhibited. When the cyclooxygenase is inhibited, the thromboxane A2 cannot be formed (Putri et al., 2014). Thromboxane A2 is a type of thromboxane that is produced by activated platelets during hemostasis and has prothomrobiotic properties. It stimulates new platelet activation and increases platelet aggregation. Platelets and platelet destruction in thrombus clotting will be inhibited so the bleeding time will increase. Aspirin blocks the production of thromboxone A2 by acetylating residues near the active site of cyclooxygenase which is an enzyme that produces precursor endoperoxide cyclic thromboxane A2 (Memah, 2014).

Instead of using chemical drugs, medicinal plants could be used. One of the plants is Ipomoea batatas L. or known as sweet potato. It can increase the number of platelets by $224 \%$ because it contains polyphenol compounds, flavonoids (Hidayati \& Harjono, 2017; Wati et al., 2014), and tannins (Nurhudiman et al., 2018; Rabbaniyah, 2015).

Phytochemical and pharmacological tests show that Billygoat Weed (Ageratum conyzoides) contains several chemical compounds, namely alkaloids, flavonoids, polyphenols, and tannins (Hikmah et al., 2018).

\section{CONCLUSIONS AND SUGGESTIONS}

Based on the research result, it can be concluded that the Billygoat Weed (Ageratum conyzoides) leaf extract can increase the platelet counts with a dose of $3.36 \mathrm{mg} / \mathrm{kgBW}$. Other studies on Billygoat Weed (Ageratum conyzoides) need to be done in increasing the platelet counts of male mice (Mus musculus) with dengue fever with the right media and dosage. It is hoped that this research can be used as a reference for further research.

\section{REFERENCES}

Aini, M., Ali, M., \& Putri, B. (2014). Penerapan teknik imotilisasi benih ikan nila (Oreochromis niloticus) menggunakan ekstrak daun bandotan (Ageratum conyzoides) pada transportasi basah. E-Jurnal Rekayasa Dan Teknologi Budidaya Perairan, 2(2), 217-226.

Anwar, A. Y. (2018). Penentuan Kriteria Penilaian Kesan Jumlah Trombosit Pada Pemeriksaan Apusan Darah Tepi. Jurnal Kesehatan Panrita Husada, 3(2), 93-100.

Bahctiar, A. R. (2019). Platelet And Hemoglobin Concentration In Tuberculosis Patients With AntiTuberculosis Medication. Jurnal Media Analis Kesehatan, 10(2), 143-151.

Firani, N. K. (2018). Mengenali Sel-Sel Darah dan Kelainan Darah. Universitas Brawijaya Press.

Hajiriah, T. L., \& Intan, P. K. (2019). Uji Efektifitas Getah Jarak Pagar (Jatropha Curcas) Sebagai Obat Pengganti Antiseptik Kimia. Jurnal Kependidikan: Jurnal Hasil Penelitian Dan Kajian Kepustakaan Di Bidang Pendidikan, Pengajaran Dan Pembelajaran, 5(2), 141-148. 
Hidayati, A. S., \& Harjono, H. (2017). Uji Aktivitas Antibakteri Krim Ekstrak Daun Babadotan (Ageratum conyzoides. L) dalam Pelarut Etanol. Jurnal Mipa, 40(1), 33-38.

Hikmah, A. U., Bilkis, F. G., \& Maelani, D. G. (2018). Pemanfaatan Ekstrak Daun Babandotan (Ageratum Conyzoides) Sebagai Bioherbisida Gulma Rumput Teki (Cyperus Rotundus). Ekologia: Jurnal Ilmiah Ilmu Dasar Dan Lingkungan Hidup, 18(1), 25-30.

Irawati, N. A. V. (2015). Antihypertensive effects of avocado leaf extract (Persea Americana mill). Jurnal Majority, 4(1).

Isda, M. N., Fatonah, S., \& Fitri, R. (2013). Potensi Ekstrak Daun Gulma Babadotan (Ageratum conyzoides L.) terhadap Perkecambahan dan Pertumbuhan Paspalum conjugatum Berg. Al-Kauniyah: Jurnal Biologi, 6(2), 120-125.

Karsy, M., Henderson, F., Tenny, S., Guan, J., Amps, J. W., Friedman, A. H., Spiotta, A. M., Patel, S., Kestle, J. R., \& Jensen, R. L. (2018). Attitudes and opinions of US neurosurgical residents toward research and scholarship: A national survey. Journal of Neurosurgery, 131(1), 252-263.

Khasanah, A. N., \& Suyadi, S. (2014). Studi Jumlah Trombosit Antara Pendonor Laki-Laki Dan Perempuan Pada Usia Yang Berbeda Di Unit Transfusi Darah Cabang Kota Malang. Florea: Jurnal Biologi Dan Pembelajarannya, 1(1).

Lubis, A. M., Sudoyo, A. W., Effendy, S., Djumhana, T. B., \& Harimurti, K. (2015). Hubungan Antibodi Anti Trombosit terhadap Respon Transfusi Trombosit pada Pasien HematoOnkologi yang Mendapatkan Multitransfusi Trombosit di RS Dr.
Cipto Mangunkusomo. Jurnal Penyakit Dalam Indonesia, 2(4), 200-207.

Lumowa, S. V. V. (2011). Efektivitas Ekstrak Babadotan (Ageratum Conyzoides L.) Terhadap Tingkat Kematian Larva Spodoptera litura F. Eugenia, 17(3).

Masihor, J. J., Mantik, M. F., Memah, M., \& Mongan, A. E. (2013). Hubungan jumlah trombosit dan jumlah leukosit pada pasien anak demam berdarah dengue. EBiomedik, 1(1).

Memah, M. F. (2014). Hubungan Jumlah Trombosit Dan Nilai Agregasi Trombosit Pada Pasien Diabetes Melitus Tipe 2 Rsup Prof. Dr. RD Kandou Manado. EBiomedik, 2(1).

Motulo, C. Y., Mongan, A. E., \& Memah, M. F. (2015). Karakteristik trombosit pada pasien anak dengan infeksi virus dengue di manado. EBiomedik, 3(2).

Nurhudiman, N., Hasibuan, R., Hariri, A. M., \& Purnomo, P. (2018). Uji Potensi Daun Babadotan (Ageratum Conyzoides L.) Sebagai Insektisida Botani Terhadap Hama (Plutella Xylostella L.) Di Laboratorium. Jurnal Agrotek Tropika, 6(2).

Putri, R. R. R. F., Ulfa, E. U., \& Riyanti, R. (2014). Uji Aktivitas Antiplatelet Ekstrak Etanol Kubis Merah (Brassica oleracea var. Capitata L.) Antiplatelets activity of red cabbage ethanolic extract (Brassica oleracea var. Capitata L.). Pustaka Kesehatan, 2(1), 111-114.

Rabbaniyah, F. (2015). Pengaruh Pemberian Ekstrak Daun Jambu Biji (Psidium guajava Linn.) terhadap Peningkatan Trombosit pada Pasien Demam Berdarah Dengue. Jurnal Majority, 4(7), 91-96.

Rasyada, A., Nasrul, E., \& Edward, Z. (2014). Hubungan nilai hematokrit terhadap 
jumlah trombosit pada penderita demam berdarah dengue. Jurnal Kesehatan Andalas, 3(3).

Rofinda, Z. D. (2012). Kelainan hemostasis pada leukemia. Jurnal Kesehatan Andalas, 1(2).

Shalehah, A., Cahaya, N., \& Fadlilaturrahmah, F. (2015). Pengaruh Pemberian Ekstrak Etanol Daun Kajajahi (Leucosyke capitellata Wedd.) Terhadap Efek Pembekuan Darah Dan Penurunan Agregasi Platelet Pada Darah Manusia Sehat Secara In Vitro. PHARMACY: Jurnal Farmasi Indonesia (Pharmaceutical Journal of Indonesia), 12(2), 140-152.

Sugianto, C. A., \& Zundi, T. M. (2017). Rancang Bangun Aplikasi Donor Darah Berbasis Mobile di PMI Kabupaten Bandung. KOPERTIP: Jurnal Ilmiah Manajemen Informatika Dan Komputer, 1(1), 11-18.

Sundaryono, A., Firdaus, M. L., Firdaus, S., \& Karyadi, B. (2016). Potensi Ekstrak Daun Tanaman Betadin Untuk Meningkatkan Jumlah Trombosit Penderita Dbd Melalui Uji Terhadap Mus Musculus. Seminar Nasional Pendidikan Sains VI 2016.

Syam, J., Tolleng, A. L., \& Umar, U. (2016). Pengaruh Pemberian Pakan Konsentrat Dan Urea Molases Blok (UMB) Terhadap Hemoglobin Sapi Potong. TEKNOSAINS: MEDIA INFORMASI SAINS DAN TEKNOLOGI, 10(1), 103110.

Ujiani, S., Tuntun, M., \& Hasibuan, T. M. R. (2018). Perbedaan Nilai PDW, MPV, Dan Jumlah Trombosit Pada Pre Dan Post Hemodialisa Pasien Gagal Ginjal Kronik. Jurnal Analis Kesehatan, 7(1), 649-656.
Utari, F. P., Efrida, E., \& Kadri, H. (2018). Perbandingan Nilai Hematokrit dan Jumlah Trombosit antara Infeksi Dengue Primer dan Dengue Sekunder pada Anak di RSUP. Dr. M. Djamil. Jurnal Kesehatan Andalas, 7(1), 118123.

Wati, I. F., Efri, E., \& Maryono, T. (2014). Keefektifan Ekstrak Daun Sirih dan Daun Babadotan Mengendalikan Penyakit Antraknosa Pada Buah Cabai (Capsicum annum L.). Jurnal Agrotek Tropika, 2(3).

Wijaya, S. (2020). Immune Thrombocytopenia. Cermin Dunia Kedokteran, 46(11), 658-661.

Wirawan, R. (2007). Nilai Rujukan Pemeriksaan Agregasi Trombosit dengan Adenosin Difosfat pada Orang Indonesia Dewasa Normal di Jakarta. Majalah Kedokteran Indonesia, 57(7), 212-219.

Yolanda, A., \& Kurnia, R. (2015). Penentuan Klasifikasi Tingkat Stadium Demam Berdarah Dengue (Dbd) Berdasarkan Jumlah Sel Darah Putih Berbasis Image Processing. Poli Rekayasa, 10(2), 1-11.

Yolanda, A., \& Prayama, D. (2016). Perhitungan Jumlah Trombosit Untuk Penentuan Tingkat Penyakit Demam Berdarah Melalui Image Processing. National Conference of Applied Engineering, Business and Information Technology, Politeknik Negeri Padang, 17-25.

Yuliani, N. (2013). Penerapan Strategi SQ3R Untuk Meningkatkan Keterampilan Membaca Intensif Siswa Kelas IV Sekolah Dasar. Jurnal Penelitian Pendidikan Guru Sekolah Dasar, 1(2), 1-10. 
Biosfer: Jurnal Tadris Biologi, 10 (1) (2020) 51 - 57

Yessy Velina, Nirva Diana, Aulia Annisa

Zulkarnain, I., Surarso, B., \& Purnami, N. (2017). Penurunan hemoglobin, pascakemoterapi cisplatin-paclitaxel neutrofil, dan trombosit pada penderita tumor ganas kepala dan leher. Jurnal THT. 